\title{
Serum immunoglobulins in a rural and an urban population of Greece with special reference to immunoglobulin A
}

\author{
J. ECONOMIDOU, O. MANOUSOS, D. TRICHOPOULOS, J. TRIANTAPHYLLIDIS, \\ T. TSICRICAS, AND G. MERIKAS
}

From the Second Department of Medicine and the Department of Hygiene and Epidemiology, University of Athens Medical School, Athens, Greece

SUMMARY The serum concentration of immunoglobulins $\mathbf{G}, \mathbf{A}$, and $\mathbf{M}$ was studied in 390 inhabitants of a rural community and in 204 residents of an urban area of Greece. It was found that serum IgA levels were significantly higher in the rural area where intestinal infections were more prevalent. No significant difference in serum IgG was found between the two groups. IgM was found to be lower among residents of the rural area. The present findings suggest a possible ecological association between increased $\operatorname{IgA}$ and chronic exposure to intestinal infection.

The demonstration that IgA is the principal class of immunoglobulin in external secretions and that it is the main immunoglobulin made by plasma cells in mucous membranes of the gastrointestinal tract (Crabbé et al., 1965) has stimulated great interest in recent years. The description of alpha chain disease ( $\alpha$-CD) by Seligmann et al. (1968), which presents as a benign or neoplastic aberration of the IgA secretory system, has led to the observation that this disease affects mainly individuals living in areas with a high degree of intestinal infestations and low socioeconomic background (Seligmann et al., 1971). This peculiar geographic distribution of patients with $\alpha-C D$ and 'Mediterranean lymphoma', which is closely related to $\alpha$-CD (Doe, 1975), strongly suggests that environmental factors providing a sustained antigenic stimulation of the $\operatorname{IgA}$ secretory system may initiate a diffuse proliferation of plasma cells in the gut mucosa. This process can be reversible or eventually resume a malignant character (Rambaud and Matuchansky, 1973; Seligmann, 1975). It is noteworthy that, of the four cases with $\alpha$-CD seen in Greece, two lived in villages with poor hygienic conditions and the other two came from very low income families (Manousos, 1975; Economidou et al., 1976; Economidou, unpublished observations).

The situation with regard to the origin of serum $\operatorname{IgA}$ in humans is not quite clear. The intestinal IgA

Received for publication 27 March 1979 immunocytes produce varying proportions of monomers and polymers (Brandtzaeg and Baklien, 1977), and although the main secretory product is oligomeric it is believed that the gut-associated lymphoid tissue is probably a significant source of the monomeric serum IgA in man (Lamm, 1976).

Thus we decided to examine the serum immunoglobulin levels in two populations with different degrees of exposure to intestinal pathogens in order to test the hypothesis that chronic intestinal infection may cause changes in secretory IgA production which will be reflected in the serum IgA levels.

\section{Material and methods}

A total of 594 persons of both sexes aged 17 to 70 years was studied; 390 lived in a rural area of central Greece (Thessaly). This area was chosen because of its poor hygienic conditions (the water supply is pumped from open wells and there is no sewage system) and because two of the index cases of $\alpha-C D$ originated from these village communities. A group of 204 permanent inhabitants of Athens matched for age and sex served as controls. The persons tested were selected at random. They were given a complete physical examination and their previous history of infection with special reference to brucellosis, typhoid, paratyphoid infections, and history of frequent attacks of diarrhoea was recorded as well as their body weight and height. Subjects with a history of chronic illness which might have influenced the immunoglobulin levels, for example, 
renal failure, cirrhosis, rheumatoid arthritis, alcoholism, etc, were not included in this series. Also subjects showing evidence of acute infection were excluded.

All blood samples were screened for protein abnormalities by serum electrophoresis. Quantitative determination of IgA, IgG, and IgM was performed by the radial immunodiffusion technique (Mancini et al., 1965) using commercially obtained immunoplates and standard serum (Meloy Laboratories, Springfield, Va, USA). Serum immunoelectrophoresis and the immunoselection plate technique for the detection of free alpha chains (Doe et al., i972) was carried out in selected cases. The hepatitis B surface antigen (HBsAg) was detected by the reverse haemagglutination technique (Hepanosticon, Organon).

Statistical analysis was performed after logarithmic transformation of the immunoglobulin values using standard analysis of variance techniques (Armitage, 1971). In duplicate measurements, the analytical error for $\operatorname{IgG}, \operatorname{IgA}$, and $\operatorname{IgM}$ was $5 \cdot 8 \%$, $4.9 \%$, and $10.7 \%$ respectively (Carlson, 1960 ).

Table 1 Distribution of subjects according to age, sex, and urban-rural residence

\begin{tabular}{|c|c|c|c|c|}
\hline \multirow{2}{*}{$\begin{array}{l}\text { Age group } \\
\text { (years) }\end{array}$} & \multicolumn{2}{|l|}{ Urban } & \multicolumn{2}{|l|}{ Rural } \\
\hline & Males & Females & Males & Females \\
\hline $\begin{array}{l}-29 \\
30-39 \\
40-49 \\
50+\end{array}$ & $\begin{array}{l}30 \\
20 \\
32 \\
20\end{array}$ & $\begin{array}{l}40 \\
18 \\
21 \\
23\end{array}$ & $\begin{array}{l}79 \\
39 \\
68 \\
39\end{array}$ & $\begin{array}{l}70 \\
28 \\
38 \\
29\end{array}$ \\
\hline Total & 102 & 102 & 225 & 165 \\
\hline
\end{tabular}

Table 2 History of infection in subjects of urban or rural residence

\begin{tabular}{|c|c|c|c|c|c|}
\hline \multirow[t]{2}{*}{ Residence } & \multirow{2}{*}{$\begin{array}{l}\text { Number } \\
\text { examined }\end{array}$} & \multicolumn{3}{|c|}{ Percent with histories of: } & \multirow{2}{*}{$\begin{array}{l}\text { Percent } \\
\text { preva- } \\
\text { lence } \\
\text { of } \mathrm{HBs} \mathrm{Ag}\end{array}$} \\
\hline & & $\begin{array}{l}\text { Salmonel- } \\
\text { losis }\end{array}$ & $\begin{array}{l}\text { Brucel- } \\
\text { losis }\end{array}$ & $\begin{array}{l}\text { Frequent } \\
\text { diarrhoea }\end{array}$ & \\
\hline $\begin{array}{l}\text { Urban } \\
\text { Rural }\end{array}$ & $\begin{array}{l}204 \\
390\end{array}$ & $\begin{array}{l}1 \cdot 5 \\
6 \cdot 7\end{array}$ & $\begin{array}{l}0 \cdot 0 \\
5 \cdot 4\end{array}$ & $\begin{array}{l}0.5 \\
7 \cdot 2\end{array}$ & $\begin{array}{l}0.5 \\
5 \cdot 9\end{array}$ \\
\hline
\end{tabular}

\section{Results}

The distribution of the 594 examined subjects according to age, sex, and urban or rural residence is shown in Table 1. Histories of infection from all persons summarised in Table 2 indicate that in the rural area the frequency of gastrointestinal infection and episodes of diarrhoea is much higher than in the urban area. The initial screening of the serum samples by electrophoresis on cellulose acetate revealed a paraprotein spike in two persons living in different villages. The paraproteins were characterised as monoclonal $\operatorname{IgA} \lambda$ and $\operatorname{IgG} \lambda$ respectively. All sera with raised immunoglobulin levels were also further analysed by immunoelectrophoresis, and sera with increased IgA were studied by the immunoselection plate technique for the detection of free alpha chains. This investigation did not reveal any additional cases of monoclonal immunoglobulins. Among the 594 examined subjects, two, both males from the rural area, were found to have no detectable levels of IgA. These cases with selective IgA deficiency were excluded from all further analysis since this abnormality is considered to be genetically determined (Goldberg et al., 1968; Nell et al., 1972).

Serum concentrations of IgG, IgA, and IgM according to sex and rural or urban residence were analysed after logarithmic transformation of the individual values because the respective frequency distributions were positively skewed. The geometric mean values and the log-normal range for each immunoglobulin class are shown in Table 3.

With respect to serum IgG, there was clearly no sex effect, and no significant difference was found between rural and urban residents.

With respect to serum IgA there was again no sex difference. However it was found that the rural sample had significantly higher serum IgA than the urban sample ( $t$ value 2.06 , with $590 \mathrm{df} ; \mathrm{P}<0.05$ ).

By examining the IgM data it was observed that the IgM concentration was significantly higher in females in both the rural and urban populations $(P<0.001)$. On the other hand, residents of urban areas had a higher mean serum IgM concentration than residents of rural areas, and this was true for both men $(P<0.02)$ and women $(P<0.02)$. The

Table 3 Geometric mean values and log-normal range of serum immunoglobulins according to urban or rural residence

\begin{tabular}{|c|c|c|c|c|}
\hline \multirow{2}{*}{$\begin{array}{l}\text { Immunoglobulin } \\
(\mathrm{gl})\end{array}$} & \multicolumn{2}{|l|}{ Urban } & \multicolumn{2}{|l|}{ Rural } \\
\hline & Males & Females & Males & Femoles \\
\hline $\begin{array}{l}\text { IgG } \\
\text { IgA } \\
\text { IgM }\end{array}$ & $\begin{array}{c}11 \cdot 48 \\
(7 \cdot 83-16 \cdot 83) \\
1 \cdot 86 \\
(0 \cdot 65-5 \cdot 37) \\
1 \cdot 20 \\
(0 \cdot 38-3 \cdot 77)\end{array}$ & $\begin{array}{c}12.02 \\
(8 \cdot 20-17 \cdot 62) \\
1.82 \\
(0.68-4 \cdot 88) \\
1.95 \\
(0.54-6.98)\end{array}$ & $\begin{array}{c}11 \cdot 75 \\
(7 \cdot 24-19 \cdot 05) \\
2 \cdot 00 \\
(0 \cdot 84-4 \cdot 74) \\
1 \cdot 05 \\
(0 \cdot 38-2 \cdot 91)\end{array}$ & $\begin{array}{c}12 \cdot 02 \\
(7 \cdot 41-19 \cdot 50) \\
2 \cdot 00 \\
(0 \cdot 94-4 \cdot 23) \\
1 \cdot 70 \\
(0 \cdot 52-5 \cdot 55)\end{array}$ \\
\hline
\end{tabular}


effect of height on IgM concentration was also examined, and a weak positive correlation between these two factors was found $(r=+0.13$ for males and $r=+0 \cdot 10$ for females).

\section{Discussion}

In Greece, the mortality from infectious and parasitic diseases and the prevalence of parasitoses is higher in the rural than in the urban parts of the country (Constandinidis et al., 1974; Kaladiti et al., 1977). Extensive studies in large groups of the population have shown that there is a significantly greater frequency of markers for hepatitis B infection in the rural than in the urban areas (Blumberg et al., 1975; Trichopoulos et al., 1976).

The above cited evidence implied that the rural populations of the country are exposed to intestinal infections more often than the urban ones. This was clearly confirmed by our investigation, which showed a higher prevalence of $\mathrm{HBsAg}$ carrier state and a more frequent reporting of salmonellosis, brucellosis, and undiagnosed attacks of diarrhoea in the rural area studied. For this reason we thought it sufficient to compare the levels of serum immunoglobulins in the two groups instead of analysing individual cases with and without intestinal infections.

The levels of IgG were not found to be raised in the village communities studied in spite of the evidence for a higher prevalence of infection. The increased levels of IgG and IgM which have been observed in certain communities of developing countries have been attributed mainly to exposure to malaria, trypanosomiasis, or other parasitic infestations which are not endemic in Greece (Zegers et al., 1973; McGregor et al., 1970).

The occurrence of higher IgM levels in females than in males has been reported several times (McGregor et al., 1970; Butterworth et al., 1967) and has been observed in the present study. The existence of a weak positive correlation between height and IgM concentration, which has been demonstrated in the analysis of our data, might explain the difference noted, since in Greece urban residents are taller than inhabitants of rural areas (Georgiadis et. al., 1969).

Our main finding was that serum IgA was significantly higher in the rural area. This suggests that there might be an ecological correlation between serum IgA and intestinal infection.

The occurrence in certain countries of Mediterranean lymphoma and $\alpha-C D$ has been attributed to chronic intestinal infections prevalent in these areas (Seligmann et al., 1971; Ramot et al., 1965). Eidelman et al. (1966) performed serial intestinal biopsies in healthy people from these countries and showed an increased lymphocytic and plasma cell infiltration within the lamina propria. These observations have provided support for the current view about the role of chronic intestinal infections in initiating diffuse plasmacytic proliferation in the intestinal mucosa which may eventually progress to the development of Mediterranean lymphoma or $\alpha-C D$ in genetically predisposed subjects (Seligmann, 1975; Rappaport et al., 1972). However, the relation of intestinal infection to serum IgA has not been specifically studied in large population samples of healthy people. The results of the present work provide some support to the concept that chronic antigenic exposure of the gut mucosa causes a susstained stimulation of the IgA secretory system which may be reflected by increased serum IgA levels.

This work was supported by a Wellcome Trust grant number BH/PH5186.

\section{References}

Armitage, P. (1971). Statistical Methods in Medical Research, p. 288. Blackwell, Oxford.

Blumberg, B. S., Hesser, J. E., Economidou, J., Hadziyannis, S., Giustozi, A., and Livadas, D. (1975) The variety of responses within a community to infection with Australia (hepatitis B) antigen. Developments in Biological Standardization, 30, 270-283.

Brandtzaeg, P., and Baklien, K. (1977). Intestinal secretion of IgA and IgM: a hypothetical model. In Immunology of the Gut (Ciba Foundation Symposium, New Series, 46), pp. 77-113. Elsevier/Excerpta Medica/ North-Holland, Amsterdam.

Butterworth, M., McClellan, B., and Allansmith, M. (1967). Influence of sex on immunoglobulin levels. Nature, 214, 1224-1225.

Carlson, L. A. (1960). Serum lipids in normal men. Acta Medica Scandinavica, 167, 377-397.

Constandinidis, E., Kalapothaki, V., Pimenidou, E., and Papadakis, J. (1974). Research on enteric parasites among the Hellenic Army recruits. Iatriki Epitheorisis Enoplon Dynameon, 8, 389-392.

Crabbé, P. A., Carbonara, A. O., and Heremans, J. F. (1965). The normal human intestinal mucosa as a major source of plasma cells containing A immunoglobulin. Laboratory Investigation, 14, 235-248.

Doe, W. F. (1975). Alpha chain disease. Clinicopathological features and relationship to so-called Mediterranean lymphoma. British Journal of Cancer, 31, Supplement 2, 350-355.

Doe, W. F., Henry, K., Hobbs, J. R., Avery Jones, F., Dent, C. E., and Booth, C. C. (1972). Five cases of alpha chain disease. Gut, 13, 947-957.

Economidou, J. C., Manousos, O. N., and Katsaros, D. (1976). Alpha-chain disease causing kaliopenic nephropathy and fatal intestinal perforations. American 
Journal of Digestive Diseases, 21, 577-585.

Eidelman, S., Parkins, R. A., and Rubin, C. E. (1966). Abdominal lymphoma presenting as malabsorption: a clinico-pathologic study of nine cases in Israel and a review of the literature. Medicine, 45, 111-137.

Georgiadis, E., Trichopoulos, D., Chilaiditis, G., Polychronopoulos, A., and Sparros, L. (1969). Influence of socio-economic factors of the stature of the Greek population. (In Greek.) Iatrika Chronica, 9, 3-8.

Goldberg, L. S., Barnett, E. V., and Fudenberg, H. H. (1968). Selective absence of IgA: A family study. Journal of Laboratory and Clinical Medicine, 72, 204-212.

Kaladiti, A., Avramidis, D., Xirouchaki, E., Sparros, L., Papaevangelou, G., and Trichopoulos, D. (1977). Comparison of mortality from various causes in urban and rural areas of Greece. (In Greek.) Iatriki, 31, 57-63.

Lamm, M. E. (1976). Cellular aspects of immunoglobulin A. Advances in Immunology, 22, 223-290.

McGregor, I. A., Rowe, D. S., Wilson, M. E., and Billewicz, W. Z. (1970). Plasma immunoglobulin concentrations in an African (Gambian) community in relation to season, malaria and other infections and pregnancy. Clinical and Experimental Immunology, 7, 51-74.

Mancini, G., Carbonara, A. O., and Heremans, J. F. (1965). Immunochemical quantitation of antigens by single radial immunodiffusion. Immunochemistry, 2, 235-254.

Manousos, O. N. (1975). Alpha-chain disease. In Topics in Gastroenterology, volume 3, edited by S. C. Truelove and M. J. Goodman, pp. 259-271. Blackwell, Oxford.

Nell, P. A., Ammann, A. J., Hong, R., and Stiehm, E. R. (1972). Familial selective IgA deficiency. Pediatrics, 49, 71-79.
Rambaud, J. C., and Matuchansky, C. (1973). Alphachain disease. Lancet, 1, 1430-1432.

Ramot, B., Shahin, N., and Bubis, J. J. (1965). Malabsorption syndrome in lymphoma of small intestine. A study of 13 cases. Israel Journal of Medical Sciences, 1, 221-226.

Rappaport, H., Ramot, B., Hulu, N., and Park, J. K. (1972). The pathology of so-called Mediterranean abdominal lymphoma with malabsorption. Cancer, 29, 1502-1511.

Seligmann, M. (1975). Alpha-chain disease: immunoglobulin abnormalities pathogenesis and current concepts. British Journal of Cancer, 31, Supplement 2, 356-361.

Seligmann, M., Danon, F., Hurez, D., Mihaesco, E., and Preud'homme, J. L. (1968). Alpha chain disease: a new immunoglobulin abnormality. Science, 162, 1396-1397.

Seligmann, M., Mihaesco, E., and Frangione, B. (1971). Studies on alpha chain disease. Annals of the New York Academy of Sciences, 190, 487-500.

Trichopoulos, D., Papaevangelou, G., Violaki, M., Vissoulis, C., Sparros, L., and Manousos, O. N. (1976). Geographic correlation between mortality from primary hepatic carcinoma and prevalence of hepatitis B surface antigen in Greece. British Journal of Cancer, 34, 83-87.

Zegers, B. J. M., Geerdink, R. A., and Sander, P. C. (1973). Serum immunoglobulin levels in Trio and Wajana Indians of Surinam. Vox Sanguinis, 24, 457-467.

Requests for reprints to: Dr J. Economidou, Second Department of Medicine, Hippokration General Hospital, 114, Vass. Sophias Ave., Athens (610)-Greece. 